\title{
PUERTO GALA Y PUERTO GAVIOTA (1985-1993): UNA MIRADA DESDE EL TRIÁNGULO DE LA VIOLENCIA
}

ALEJANDRO MARÍN LLEUCÚNa

\begin{abstract}
RESUMEN
Puerto Gala y Puerto Gaviota son los pueblos de fundación más reciente en nuestro país. Sus orígenes los podemos encontrar en la década de 1980 y obedecen a un proceso de migración espontánea, generado por la explotación del recurso merluza. Esta primera etapa de poblamiento se ve reflejada en el nomadismo de su población flotante, pero también en una serie de hechos de violencia, de los cuales se tiene poco conocimiento, aunque han servido para estigmatizar ambas localidades. A partir de esta premisa, nuestro trabajo tiene como objetivo realizar un análisis al proceso de migración y sus consecuencias en el litoral aysenino, desde la perspectiva del triángulo de la violencia (Johan Galtung).
\end{abstract}

PALABRAS CLAVES: Poblamientos espontáneos, Dictadura, Violencia estructural, Violencia económica, Violencia simbólica.

\section{PORT OF GALA AND PORT OF GAVIOTA (1985-1993): A LOOK FROM THE TRIANGLE OF VIOLENCE}

\begin{abstract}
Port of Gala and Port of Gaviota are the most recent foundation villages in our country. We can find their origins in 1980 decade as a consequence of a spontaneous migration, which was caused by the tapping of hake resources. This first stage of town is reflected in the nomadism of its floating population and in violent incidents which are unknown, although they were used for stigmatizing both villages. Starting from this premise, our objective is to analyze the migration process and its consequences in the coast of Aysén, from the perspectives of the triangle of the violence (Johan Galtung).

KEY WORDS: to settle people spontaneously, Dictatorship, Structural violence, Economic Violence, Symbolic violence.

a Profesor de Historia y Geografía (Colegio Mater Dei Coyhaique) e Investigador de la Sociedad de Historia y Geografía de Aysén. keeptheflames@gmail.com
\end{abstract}




\section{INTRODUCCIÓN}

Puerto Gala y puerto Gaviota son dos localidades que se encuentran ubicadas en el litoral norte de la región de Aysén ${ }^{1}$. El proceso de ocupación de estos espacios territoriales, se puede resumir en tres etapas: "migración espontánea", "sedentarización" y el "reconocimiento legal por parte del Estado chileno" (1999). La historia de estas comunidades se encuentra íntimamente ligada a la cultura de la pesca artesanal, la cual mantiene en la actualidad una la lucha constante por sobrevivir a los problemas que aquejan la subsistencia de este sector pesquero (Brinck et al. 2011). La capacidad de resiliencia de estas localidades, han sido un fiel ejemplo de todo el esfuerzo que han desplegado sus habitantes para poder vivir en esta recóndita zona de nuestro país. Todo este largo proceso de integración, ha sido obra de la autogestión de sus propias organizaciones de bases y el aporte espiritual y material del Padre José Antonio Ronchi Berra.

Actualmente estos pueblos se encuentran amenazados por la competencia desigual que han tenido que librar contra la pesca industrial. La disminución de sus cuotas de extracción -por parte del Estado- y el agotamiento de la biomasa de la merluza austral, han deteriorado sus formas de vida y su proyecciones a futuro ${ }^{2}$. A esta problemática se suma otra barrera la cual ha deteriorado aún más la percepción que se tiene de sus habitantes; referimos a las consecuencias del ciclo de la violencia que acarrea consigo la estigmatización.

Los relatos que se tejen en torno a sus primeros habitantes suelen ser asociados a hechos de sangre, delincuencia, desenfreno y marginalidad, por ende, suelen ser conocidos como los "pueblos sin dios ni ley o el Far West criollo"3. Sin embargo, nunca se ha realizado una investigación a fondo, que respalde o avale la veracidad o falsedad de los hechos que sucedieron en estas islas. Estos elementos son los que nos hacen plantearnos las siguientes interrogantes: ¿Cuál es el origen de la violencia en estas islas? ¿Qué relación existe entre estos

1 Puerto Gala se ubica $44^{\circ} 15^{\prime} 28^{\prime \prime} \mathrm{S} / 73^{\circ} 12^{\prime} 46^{\prime \prime} \mathrm{W}$ y puerto Gaviota se ubica $44^{\circ} 40^{\prime} \mathrm{S} 73^{\circ} 10^{\prime} \mathrm{O}$, en la isla Magdalena. (Fig. 1).

2 A estos problemas, debemos agregar el deterioro de sus propias organizaciones internas (desunión y conflictos entre poblamientos espontáneos y la violencia presente en la colonización tardía de Aysén? y ¿Por qué la gente tiene una imagen peyorativa de estos pueblos?

A partir de estas dudas es que surge nuestro trabajo de investigación, cuyo objetivo principal es registrar la historia del proceso de migración espontánea que se vivió en puerto Gala y puerto Gaviota, utilizando como herramienta de análisis la teoría del triángulo de violencia. Para ello, hemos recurrido al sociólogo Johan Galtung, el cual nos ofrece una aproximación al concepto de la violencia. Definiéndola como todo aquello, que siendo evitable, obstaculiza o no facilita el desarrollo humano o el crecimiento de sus capacidades potenciales (Galtung, 1995, pp. 313-315). Esto quiere decir que la insatisfacción de las necesidades básicas o su obstrucción, conllevan directamente a la presencia de la violencia. A continuación, y basándonos en el modelo de Galtung, proponemos una teoría que relaciona tres tipos de violencia presentes dentro nuestras relaciones sociales (Galtung, 2003, pp. 20-21):

La violencia directa (física y/o psicológica): Es la más visible, se manifiesta a través del proceso sujeto-acción-objeto, sin tener ningún obstáculo de por medio. Este tipo de la violencia nos va a servir para explicar las muertes causadas por las peleas, trifulcas o robos, en los primeros focos migratorios.

La violencia estructural: Se dice que es invisible y es la más dañina de todas las violencias, su origen se encuentra en las estructuras, tanto físicas como organizativas, que impiden la satisfacción de las necesidades. En nuestro trabajo, nos va a ser de gran ayuda para conocer el primer proceso de migración, además del conflicto interno que se va a generó dentro del escenario pesquero.

La violencia cultural o simbólica: Es el tipo de violencia que aborda directamente diversos elementos que conforman el concepto de cultura (símbolos, lengua, religión, ideología,

los sindicatos), la mala distribución de las cuotas de pescas y la mala gestión de las consultoras de pesca en la Región de Aysén.

3 Véase http://wiki.ead.pucv.cl/index.php/Puerto_Gala; ciudad_de_aguas 
etc.) y se encarga de legitimar la violencia directa y estructural. La violencia cultural nos puede servir para comprender el estigma social, con el cual tienen que cargar estos pueblos (exaltación de la violencia directa), además de la justificación que va tuvo el Estado para tratar de erradicarlos (violencia estructural).

Las fuentes que vamos a utilizar, son relatos orales de los habitantes de estas islas, recogidos por medio de entrevistas realizadas en el año 2008 en puerto Gala y el 2011 en puerto Gaviota. Para contrastar los testimonios de sus actores sociales directos, utilizaremos algunos libros, archivos judiciales, diarios y revistas de la época (1985-1993).

\section{Algunos antecedentes de \\ la violencia en el litoral aysenino}

La historia de nuestro poblamiento costero abarca desde la aparición de sus antiguos canoeros -nómades del mar- hasta el reconocimiento legal de los dos últimos pueblos fundados por el Estado chileno. Al realizar una mirada retrospectiva de sus hechos y acontecimientos más significativos, no solamente vamos a encontrar una visión idealizada de la gesta o el esfuerzo de su poblamiento efectivo, si no que también es posible identificar una serie de episodios de violencia. Provocados por la expansión territorial de las empresas económicas privadas, el proceso de colonización tardía -impulsada por el Estado chileno- y finalmente la dictadura militar, la cual se relaciona directamente con nuestro tema de estudio.

Durante el antiguo régimen colonial y el período post independencia, el choque cultural entre españoles e indígenas, y posteriormente entre chilenos e indígenas, estuvo marcado por la violencia constante que se ejerció en contra de los nómades del mar -Chonos-. Su instalación en diferentes misiones y el posterior contacto con los blancos, les van a significar el desarraigo de sus costumbres (enfermedades, vicios y desadaptación) y el posterior abandono de sus hábitats naturales. Paralelamente al proceso de aculturación de nuestros pueblos originarios, a mediados del siglo XIX, la violencia intensificó con el surgimiento del "boom maderero del ciprés" y la explotación de diversos recursos marinos (peletería, pesca, caza, etc.).
La fundación de Melinka en 1859 y la designación del primer subdelegado del archipiélago de las Guaitecas y los Chonos, trajo consigo una gran cantidad de emigrantes chilotes, su estadía fue motivo de violentos episodios de sangre. El empresario maderero Felipe Westhoff (1867), recuerda los siguientes sucesos:

...Esta cantidad de jente ha sido ocasión de violencias, tropelías, asesinatos y otros crimenes, que la autoridad local no ha podido evitar por falta de fuerza armada a su disposición (...) Esa misma cantidad de peones, sin sujecion, sin Dios ni lei, puede decirse, i sin nada que le impida llevar adelante sus caprichos o fechorías (p. 450).

La explotación maderera del ciprés no solamente fue un negocio lucrativo o el inicio de un proceso de colonización, también tuvo consecuencias negativas desde el punto de vista social, ya que no existió ningún tipo de control en el litoral. Francisco Mena (1985) se refiere al contexto de la época:

(...) En la lejanía de los canales había tiempo, independencia e impunidad para cualquier acción ilícita, y la lucha entre distintos grupos de sus cargamentos derivaron incluso en verdaderas incursiones piratas (...) como el tristemente célebre Ñancupel, ajusticiado en Ancud en 1886 (...) (p. 212).

La expansión de las llamadas empresas colonizadoras en las primeras décadas del siglo XX, no estuvieron ajenas a los hechos de violencia en las costas de Aysén. Conocido es el caso de la Compañía Explotadora del Baker y la isla de los muertos en Bajo Pisagua (1906), en estas instalaciones murieron alrededor de 76 o 79 trabajadores de manera desconocida. Los rumores que se tejen en torno a sus muertes y las investigaciones que se han llevado a cabo, no han logrado determinar quién o quiénes fueron los culpables, sin embargo, las desgracias acaecidas en dicha zona, no han dejado exenta de responsabilidad a la empresa colonizadora que estaba a cargo de dicha tarea. Años más tarde, también se va a sumar un hecho de sangre, en la 
A. MARÍN

misma zona de Bajo Pisagua (1931), vemos esta vez involucrados a empleados de la Estancia Hobbs y Cía. en la muerte de tres indígenas Alacalufes. Bridges ${ }^{4}$, citado por Osorio (2012), escribió:

(...) Dos canoas de alacalufes, cuyo jefe era mestizo, aparecieron en el Bajo Pisagua, armados con dos rifles, pero una barricada de roca había sido construida previendo estos ataques. Los dos hombres que se habian quedado allí, viendo la actitud amenazante de los indios, les gritaron que se fueran y por último les tiraron un tiro sobre sus cabezas para asustarlos; esto los incitó aún más pues creyeron que sus enemigos tenían mala puntería. Una batalla pronto comenzó a librarse y esta terminó con la muerte de tres del grupo atacante (p.5).

Unos años más tarde, este hecho se esclareció, gracias a la recuperación de los partes policiales de la épocay la incorporación de testimonios orales recientes de algunos habitantes de la zona. Estos elementos demostraron refutar las versiones de los relatos oficiales y demostraron que los indígenas mantenían un intercambio comercial con los empleados de la estancia, y en el momento de los hechos, ellos fueron atacados violentamente, muriendo dos Alacalufes de sexo masculino y una mujer.

$\mathrm{Si}$ ahondamos en la historia del litoral, específicamente a mediados y a fines del siglo $\mathrm{XX}$, no solamente vamos a encontrar episodios de sangre o muertes, sino también resulta posible pesquisar algunos hechos que involucran la violencia estructural del Estado, la cual se desentiende de sus compromisos, en el momento de iniciar un poblamiento. Los procesos de colonizaciones fallidas, son una prueba fehaciente de los errores que se han cometido en el momento de formalizar los asentamientos humanos, pero también son una prueba de la violencia que ha ejercido el Estado en contra de sus propios ciudadanos. Las colonizaciones de Bajo Palena o la isla de los Leones (1889), Quitralco (1950), Melimoyu y sectores aledaños (1983), nos pueden servir para demostrar, algunos elementos propios de esta violencia:

4 Relato inédito Sinopsis del trabajo realizado en el Baker durante 28 años escrito por Lucas Bridges, presumiblemente a mediados de los años cuarenta.
La poca preocupación del Estado, respecto a las vías de comunicación, provocó el abandono de la isla de los Leones. Alfredo Weber (1903), menciona este problema en los siguientes términos:

(...) la Compañía suprimió la escala en Palena quedando la colonia a merced de sus pequeñas i pobres chalupas, que en aquellas latitudes se demoraban, a veces, hasta un mes en ir a traer provisiones, jente i correspondencia de Melinka. I asi se perdió la colonia (p. 184).

En el caso de la colonia de Quitralco, la insatisfacción de las necesidades básicas, fue fatal. Así lo demuestra el antropólogo Eugenio Aránguiz (1988) "Ocurrió entonces la muerte de una guagua. Rápidamente se armó una comisión de colonos que fue Santiago a reclamar y a exigir que se les dijese si cumplirían con la entrega de viveres (...)" (p.202).

El Estado no tuvo un compromiso serio con los colonos de Santo Domingo:

(...) No nos prometieron nada. Más aún, el documento de permiso de ocupación que firmamos señala que el Estado no se responsabiliza de ninguna cosa que nos pase; y que cualquier adelanto o mejora que se hace en el predio por parte de los colonos el Estado está facultado para retirar a los colonos sin ninguna indemnización (... $)^{5}$ (Arellano, 1986, Agosto 29).

Los colonos de Melimoyu esperaron muchos años, para poder obtener sus títulos de dominio:

(...) Organizaciones campesina, parlamentarios y diversas autoridades han reiterado la necesidad de agilizar el trabajo de mensura y entrega de los títulos correspondientes a los pobladores, que en el caso de los más antiguos, por décadas no tienen acceso al crédito en diversas entidades y por ende, no pueden progresar (...) (anónimo,

5 La colonización de Santo Domingo, en las cercanías de Melimoyu, también van formar parte del abandono y el fracaso del poblamiento en el litoral. 
1993, Julio 5, página 6).

El reciente proceso de colonización fallida, en Melimoyu y en sectores aledaños ${ }^{6}$, es una muestra del abandono de sus habitantes, la mayoría de las personas se vieron afectadas por el aislamiento y la falta de las garantías básicas para poder vivir. Paralelamente al arribo de sus colonos, se dio inicio al llamado "boom de la merluza" el cual forjó un nuevo escenario de violencia en las costas de Aysén. Para poder entender este enigmático proceso, debemos conocer el contexto de la década de los años ochenta.

\section{La década de los años ochenta y la apertura económica}

La década de los años ochenta, estuvo marcada por las protestas y las movilizaciones en contra de la dictadura militar (Weinstein, 1989), nuestro país se encontraba totalmente dividido, en un clima constante de violencia. Los partidarios de izquierda eran fuertemente perseguidos $y$ reprimidos, el accionar de los aparatos de coacción, provocó la violación sistemática de los derechos humanos (Rojas, 1988) 7 .

En el ámbito económico, la situación empeoró aún más; La recesión económica internacional, la caída del cobre, la devaluación de la moneda y el sobreendeudamiento de nuestro país, tuvieron consecuencias desastrosas en el plano laboral, sobre todo en los sectores más relegados de la población chilena. La dura crisis económica de la época, estuvo ligada a la apertura económica y la búsqueda de inversión en sectores económicos, los cuales se encontraban deprimidos. Una de las áreas más prometedoras, dentro de las actividades de corte extractivo y exportador, fue el sector pesquero. Para incrementar su inversión y fortalecer su presencia dentro de levantamiento económico, se realizaron una serie de estudios de los recursos marinos presentes en las costas de Chile, y junto con ello, se proyectaron los posibles beneficios que se podían obtener de dichos recursos.

El objetivo principal de todo este paquete de

6 Pitipalena y Guaitecas en 1989.

7 Para obtener información más detallada, véase información comisión Valech e informe de la comisión nacional de verdad y reconciliación (Informe rettig). medidas era aumentar el flujo de exportaciones no tradicionales e incentivar su inversión en empresas privadas y de capital mixto. Una de las consecuencias de la apertura comercial del sector marítimo (OECD, 2009, pp. 84-86) fue el llamado "boom de la merluza", sus altos precios, resultaron un alivio para las personas desempleadas, que sufrían los estragos de la crisis económica que se vivía desde finales de la década de los años setenta y en los años ochenta.

\section{Violencia estructural en puerto Gala y puerto Gaviota}

1. La crisis económica, el boom de la merluza y el proceso de migración al litoral norte de Aysén.

La violencia estructural vertical (Fisas, 1998, p. 28$)^{8}$, cuyo accionar nace de las instituciones de un Estado, influyó directamente en la expulsión económica de los primeros flujos migratorios que dieron vida a nuestros poblamientos espontáneos. Estos partieron desde puerto Cisnes en la Región de Aysén, posteriormente se incorporaron una gran cantidad de trabajadores del mar de la Región de Los Lagos, y finalmente atendieron al llamado casi todas las regiones de nuestro país. La pobreza existente en esa década y el boom de la merluza generaron un dinamismo constante en el litoral (...) era un proyecto económico bien atractivo debido a la situación reinante y política de ese tiempo, vale decir tiempo de dictadura, existian los empleos mínimos, pobreza (...)" (B. Carmona, com pers. 2 de febrero de 2008).

La incertidumbre laboral y los despidos en el sector público, incidieron en la búsqueda de nuevas oportunidades:

(...) con las cuestiones de los cambios que hubieron nos quitaron varias cosas, nos quitaron el sueldo, nos bajaron los viáticos, nos quitaron las movilizaciones, al final nos dejaron con un solo sueldo (...) como ya tenía mucho conocimiento sobre el mar (...) cuando me retire de CONAF, me dediqué a la pesca (...) (L. Díaz, com pers. 8 de febrero de 2011).

8 La violencia estructural vertical es la represión política, la explotación económica o la alienación cultural, que violan las necesidades de libertad, bienestar e identidad. 
Para mantener a sus familias, muchos niños y jóvenes se convirtieron en pescadores:

me vine por expectativas de trabajo primero que nada (...) yo fui campesino, trabaje en el pueblo, fui junior, fui lechero, hice hartas actividades, cuando era cabro (...) como junior gano como doce mil pesos (...) y me dijo te podrías ganar como mínimo dos luquitas diarias (...) y le dije yo, cuando nos vamos (...) (A. Álvarez, com pers. 9 de febrero de 2011)

Gran parte de las personas que viajaban eran pescadores artesanales, otros eran buzos mariscadores (...) llego más o menos el año 86, llegamos buceando y después por circunstancias de trabajo nos dedicamos a pescar la merluza (...) antes fuimos perseguidos pa`abandonar los sectores pesqueros (...) (A. Sánchez, com pers. 12 de febrero de 2011).

Algunos participaron en la construcción de la carretera austral, sin embargo, no ganaron mucho dinero (...) de la carretera austral (...) empezamos a trabajar en el empleo mínimo en Chaitén, empezamos a trabajar con quinientos cincuenta pesos mensuales (...) (O. Soto, com pers. 10 de febrero de 2011)

Otros aventureros, que habían estado privados de libertad, cambiaron positivamente sus vidas:

\section{(...) algunos que decían haber pasado por la} cárcel y que estaban en la pesca porque no encontraban otro trabajo en sus ciudades de origen. Ellos decían que el venir a la

9 En el caso de nuestros objetos de estudio, al indagar en ésta temática, nos referimos a inmigraciones internas o endo-migraciones y a las emigraciones internas $u$ endoemigraciones.

10 Los barcos de factoría sobreexplotaron la merluza y la mayoría de los productos marinos de nuestras aguas. El Decreto Ley $N^{\circ} 500$ de 1974 estableció un régimen provisional para las operaciones de pesca de barcos de bandera extranjera en aguas bajo la jurisdicción nacional, en la cual se establecían permisos para operar dentro de las 200 millas (previo pago de una matrícula de US\$1.000.- y US\$60. por cada TRG de la nave) al Sur de los $37^{\circ} \mathrm{S}$. Véase Decreto Ley $N^{\circ} 500$ de 1974. Diario Oficial de la República de Chile N²8.870, Santiago, Chile, 07 de junio de 1974.

11 A comienzos de los años ochenta, no va existir un control serio, respecto a la explotación de nuestros recursos pesca les había dado la oportunidad de construir una nueva vida, de construirse nuevamente en la interacción con otros, lo que les había sido negado en el 'norte' (...) (V. Ramírez, com pers. 16 de agosto de 2008).

$\mathrm{Al}$ analizar estos testimonios anteriormente citados, podemos apreciar que los primeros migrantes ${ }^{9}$, arribaron por una expulsión económica, la cual se relaciona directamente con la violencia estructural externa, que emana de las instituciones de un régimen autoritario. La sustitución de un Estado benefactor por otro subsidiario -decreciente en su gasto social-, sumado a la crisis económica, aumentaron el desempleo. Por consiguiente también se incrementó, la pobreza estructuralmente condicionada, la cual forma parte de la primera categoría de la violencia estructural. La insatisfacción de las necesidades materiales básicas en sus lugares de origen, incentivó el abandono de sus hogares y la búsqueda de un nuevo trabajo, esto coincidió con la apertura de las pesquerías en el mar.

Es así, como surgió el llamado "boom de la merluza", el cual responde a la adopción del sistema económico de libre mercado, cuya misión fue aumentar la explotación de los recursos marítimos ${ }^{10}$, especialmente el de la merluza ${ }^{11}$. El sector pesquero artesanal fue invitado a participar ${ }^{12}$ dentro de esta aventura, sin embargo, no tuvo los mismos beneficios y ventajas que logró conseguir la industria pesquera, ya que no eran considerados competentes (La Parra \& Tortosa, 2003, p.

naturales marinos, tampoco se pensó en la sobreexplotación. El Decreto $N^{\circ} 175$ de 1980 omitía en forma explícita las cuotas globales y no especificaba un compromiso claro con el principio del libre acceso dando a la Subsecretaria de Pesca los derechos de emisión de permisos de pesca. Así, se procedió de hecho a abrir todas las pesquerías y con ello permitir el ingreso a nuevos inversionistas que se hicieron cargo del incremento en los niveles de captura. Información disponible en biblioteca del congreso nacional de Chile: http://www.bcn.cl/carpeta_temas_profundidad/ hacia-una-nueva-ley-de-pesca.

12 "El Decreto Ley $N^{\circ} 1678$ de 1977, exime de derechos, tasas y demás gravámenes que afectan la importación de implementos y motores destinados a la pesca artesanal asî como la de repuestos y accesorios". Véase en Biblioteca del Congreso Nacional: http://www.bcn.cl/carpeta_temas_ profundidad/hacia-una-nueva-ley-de-pesca 
62) $)^{13}$ dentro del sistema capitalista:

En resumen, el pescador es un ente complejo en que las tradiciones juegan un rol desmesurado en su comportamiento como agente productor y comercializador; por otra parte, se postula la existencia de una oferta de trabajo individual de tipo retráctil, que impide que el pescador responda en forma efectiva a cambios exógenos positivos en las condiciones de mercado (...) (Subsecretaría de Pesca, 1981, p. 9).

Las pequeñas y modestas embarcaciones de los pescadores artesanales no tienen como competir con los barcos de pesca industrial que navegan pescando en los canales Puyuhuapi, Yacab, Moraleda y otros donde siempre lo han hecho los pescadores de la zona, afincados en diversos puntos de la región (anónimo, 1987, Septiembre 1%).

La brecha existente entre ambos sectores, pronto se transformó en un mesoconflicto (Rozenblum, 2007, pp. 113-117), el cual favoreció al sector pesquero industrial, en desmedro del sector pesquero artesanal. La raíz de esta disputa se encuentra en las diferencias que existen respecto a las metas que buscaban alcanzar ambos sectores, por una parte encontramos a los pescadores artesanales que intentaban satisfacer sus necesidades básicas, y por otro lado, se encuentran las empresas pesqueras que tenían como objetivo generar plusvalía:

Las autoridades tienen que considerar que aquí hay mucha gente que está viviendo de la pesca artesanal y de las industrias que están instaladas en Pto. Chacabuco y en otros puntos del litoral de Aysén, trabajando con lanchas, con botes (...) mientras los buques fabricados, procesan indiscriminadamente para irse (...) (Leal, 1986, Octubre 30).

(...) y ellos vieron el boom de la pesca en España, después llegaron en el momento

13 La violencia de tipo estructural, no solamente tiene su origen en las relaciones económicas o productivas, también puede ser explicada a partir de la opresión política, que España tuvo que hacer una veda por 40 años, y por eso emigraron ellos. Los que se hicieron ricos compraron barcos entre varios y emigraron a Chile y fue así, cinco años duro el boom de la pesca [en Chile] (...) (O. Nahuel, com pers. 11 de febrero de 2011).

Las desigualdades existentes en el reparto de los recursos marítimos y sus instrumentos de extracción, terminaron en hechos violentos:

(...) en la Capitanía de Puertos, hasta allí se presentó Sebastián Solís Figueroa que se hallaba pescando en el Canal de Moraleda a la altura de la Isla Tuamapu manteniendo sus espineles con la debida señalización, conforme a las disposiciones sobre estas faenas pesqueras. En el mismo sector pescaba el buque fábrica "Pedrosa", el cual caló su arte de pesca-espinel industrial-sobre el espinel de este artesanal que perdió 2.000 anzuelos (...) (anónimo, 1986, Septiembre 26).

La falta de apoyo al sector pesquero artesanal y su nula fiscalización -por parte del Estado-, tuvo graves consecuencias en el ámbito laboral. La inexperiencia de los pescadores, la carencia de los implementos mínimos de seguridad, el desconocimiento de la zona y el alcohol, terminaron con la vida de muchas personas:

(...) incluso una vuelta acompañé a unos comerciantes de Puerto Montt de Estero Gato vinimos con el bote a Gala y vimos unos cadáveres, había mucha gente locatele (...) navegan con mucha fuerza, a veces no alcanzan a divisar la roca que sobresale, los bajos como se llaman y por ahí chocan (...) (A, Pillancari, com pers. 13 de febrero de 2011).

cuando pasaba a una distancia de siete metros retirado de la isla "la picardia", sorpresivamente su acompañante que se encontraba en estado de ebriedad, se puso de pié en la parte anterior de la embarcación, donde perdió el equilibrio

utilizando instrumentos como la discriminación institucional que excluye a sujetos sociales específicos. 
para caer al mar, donde pereció al parecer de asfixia por inmersión (Causa Rol N ${ }^{\circ} 7.459$, Febrero de 1991, Foja n²).

Las grandes sumas de dinero que se ganaba en la pesca, gracias a la extracción de la merluza, hacían pensar que iban a mejorar la situación económica de los pescadores, sin embargo, el aislamiento geográfico y la falta de los servicios básicos, no compensaron dignamente su estadía en el litoral. Con la llegada de la democracia en los años noventa (Moulian, 2002, pp. 141-143) ${ }^{14}$, el panorama siguió siendo el mismo:

[El] Gobierno debe cumplir (...) esas familias no cuentan con atención médica (...) no concurren hasta dichos sectores las rondas médicas (...) tampoco tienen escuelas para sus hijos (...) dicha zona fue visitada por el Intendente regional Dr. Hernán Valencia y miembros del Codere y del Gobierno Regional y lo que ofreció debe cumplirse, especialmente cuando nos enfrentamos al mal tiempo (...) aquí no se puede seguir escondiendo, ni eludiendo la responsabilidad que Gobierno (...) (anónimo, 1991, Junio 3).

La sobreexplotación de la merluza y su posterior veda (Centro de análisis de políticas pública U.CHILE, 1999, pp. 254-255), agravaron aún más el escenario de la pesca. La falta de trabajo, nuevamente gatilló un proceso de migración, pero de vuelta a sus hogares de origen. A pesar de estas limitantes, algunas personas decidieron radicarse en el conjunto de islas, su estadía tuvo como principal barrera la pobreza y la exclusión social. La negación de los bienes, servicios, mercados y recursos que se asocian a la ciudadanía (Martínez, 1997, p. 23), dieron continuidad a la violencia estructural, que se mantiene hasta nuestros días.

2. La migración forzada por deudas con la justicia y por la violación a los derechos humanos

El constante dinamismo dentro de las islas, a mediados de los años ochenta, también trajo a desplazados por el régimen militar. Algunos de

14 La pobreza que se mantiene a principio de la década de los años noventa, obedece al llamado "transformismo" que ellos escapaban de la justicia, por delitos menores o por delitos graves. El aumento de la represión y la efectividad de los aparatos de coerción hacían temer a los delincuentes:

(...) aquí yo te digo que el setenta por ciento de la gente venía con alguna yayita (...) acuérdate que las torturas (...) desaparición de gente el 89, entonces que dilema tenías tú, es que si te pillaban los pacos por una pequeñita cosa, con suerte volvías a tu hogar cachai, en ese tiempo la llevaban ellos (...) (V. Coronado, com pers. 12 de febrero de 2008).

Por otra parte, también vamos a encontrar algunos disidentes políticos, que escapan de la represión militar de las urbes y de las zonas que eran fuertemente controladas por los aparatos del Estado. La violencia indirecta, generaba lazos de solidaridad y de ayuda (pacto social) entre las personas que frecuentaban las islas:

(...) acá igual hubo, disidentes políticos, que por salvar su integridad física por el motivo de ser encarcelado y también eliminado, corrían acá y como se dice nosotros mismos prestábamos ropa (...) eso sucedió (...), él fue militante y simpatizante del partido comunista y tuvo que abandonar su familia desde Rancagua y venirse para acá, entonces (...) cuando preguntaban acá ¿Conocís a tal persona? No, aunque podía estarse conversando de él (...) pero era una forma de asegurarse la espalda, porque no era un delincuente (...) (G. Cristi, com pers. 15 de febrero de 2011).

(...) también existió el problema de que mucha gente, que por las circunstancias politicas que se vivieron en los años ochenta arrancó $y$ estuvo acá, como renegados políticos o escondidos políticamente una vez que volvió la democracia esta gente ya no se sintió perseguida volvió a sus lugares de orígenes (...) se quedaron algunos (...) (B. Carmona, com pers. 2 de febrero de 2008).

sufrió nuestro país, en el cual se da continuidad al sistema económico neoliberal, con todas sus controversias actuales. 
Existieron personas cuyas familias fueron afectadas directamente por la dictadura, parte de su migración forzada se relaciona en el miedo que tenían a perder su propia vida o la necesidad de iniciar una nueva vida (...) Uno de los gestores también no se encuentra aqui fue (...) un tipo que venía de Argentina también por el régimen militar nos arrancamos (...) allá perdió un hermano y toda la onda (...)" (V. Coronado, com pers. 12 de febrero de 2008).

(...) Al hombre lo llevaron preso, se fue detenido (...) los cabros quedaron solos, los dos cabros, el que está en Gala y el que está en Chile Chico (...) y ¿Qué paso con el doctor?, no sé pos (...) hasta aquí nunca he sabido (...) (M. Yáñez, com pers. 13 de febrero de 2011).

La represión que reinaba durante este período, se entiende por la intolerancia represiva, la cual se relaciona con la privación y la violación sistemática de los derechos humanos. En nuestros casos, la violencia estructural, se manifiesta a través de los aparatos de coacción, en contra de los militantes de los partidos políticos de izquierda y las clases sociales más bajas (poblaciones marginales). Las personas que escapaban de la dictadura, temían a las consecuencias que trajo consigo el terrorismo de Estado: El exilio (Yépez del Castillo \& Herrera, 2007, pp. 168-169), la relegación política, las torturas, ejecuciones, las detenciones y desapariciones.

En puerto Gala y puerto Gaviota, los migrantes partidarios de la izquierda que temían por su vida abandonaron sus residencias por motivos de seguridad personal y familiar, su situación económica, no les permitía exiliarse en otro país. La vida en la ciudad no les brindaba ninguna esperanza de cambiar su situación actual y corrían constantemente el peligro de ser descubiertos o denunciados. Algunos, fueron afectados por la violencia directa (física y psicológica) en contra de su persona o de algún familiar, por lo tanto necesitaban buscar una salida a los traumas del golpe militar que se vivía en las zonas más habitadas. Por estos

15 Según Bourdieu, la violencia estructural (despidos, jubilaciones anticipadas, precariedad laboral, etc.) genera otros tipos de violencia (altas tazas de suicidio, criminalidad, motivos, tomaron la determinación de emigrar de las ciudades al campo y otros de su lugar de residencia a los lugares más recónditos y aislados de nuestro país, en donde la presencia del Estado y sus aparatos era mínima o casi inexistente. La región de Aysén cumplía con esos requisitos, en especial, la zona del litoral. El destape del llamado boom de la merluza, fue una oportunidad única para escapar de la dictadura y para cambiar el modo de vida que llevaban habitualmente. A comienzos de los años noventa, en concordancia con la llegada de la democracia y el agotamiento de la merluza, muchos de ellos volvieron nuevamente a sus lugares de origen.

\section{La violencia directa en puerto Gala y puerto Gaviota}

La violencia indirecta que movilizó a una gran cantidad de personas, dio paso a otro tipo de violencia, la cual afectó aún más la vida de los pescadores artesanales. Siguiendo la ley de la conservación de la violencia (Vásquez, 2002, p. 218-219) $)^{15}$, las relaciones sociales de los residentes, se vieron sometidas a la violencia directa, la cual era vista como algo normal dentro de sus vidas. Antes de comenzar a conocer las causas y los acontecimientos que estigmatizaron a nuestros poblamientos espontáneos, debemos describir el escenario, en el cual se desenvolvieron los hechos u eventos Resulta que aquí en puerto gala habíamos unas cinco mil personas (...) generalmente hombres, no familias constituidas, como las que se ven ahora, habian algunas que otras (...) (A. Manríquez, com pers. 09 de febrero de 2008)

Víctor Ramírez (1998) uno de los primeros profesores en puerto Gala, recuerda la distribución de la población:

(...) Asi los cisnenses (de Puerto Cisnes), se distribuyeron principalmente en Grupo Gala y Puerto Gaviota; los valdivianos en Grupo Gala; los chilotes en Calquemán (...) dentro

alcoholismo, etc.). En el caso de nuestros pueblos, la violencia estructural, es la que dio paso a otros tipos de violencia. 
de cada puerto se crean "caletas" ocupadas únicamente por gente que tiene comunidad de origen, y uno que otro individuo que es aceptado por amistad o parentesco (...) (p.45).

El contacto entre las caletas, era escaso, ya que el desconocimiento entre ellos no permitía el surgimiento de fuertes lazos de confianza. Las relaciones eran netamente laborales y en algunas ocasiones de solidaridad. No existía un acercamiento directo entre los pescadores, ya que se desconocía su pasado y sus costumbres:

(...) habia mucha gente antes (...) aunque tú no te habías visto nunca, pero si eras de tal parte, como eso te ayudaba y se hacian los grupos, estábamos nosotros, estábamos los cabros de Osorno, andábamos juntos los cabros de Osorno con los de Temuco (...) (A. Álvarez, com pers. 9 de febrero de 2011).

La creación de las caletas no solamente es motivo de acercamiento y unión de los coterráneos, también implica un sistema de segregación interna de los grupos de dominancia:

(...) existía esa convivencia por vista (...) ni hola, sino que la mirada, este gueón es quellonino, este gueón es lenguino, este gueón es Coquimbo (...) y cada uno formó sus caletas (...) tú no te podías meter en su caleta, cachai, porque había pesca (...) (V. Coronado, com pers. 12 de febrero de 2008).

El acercamiento y la unión de las caletas, recién se va a materializar en el momento que los pescadores van a decidir establecerse en las islas, de manera definitiva. Previo a este proceso de sedentarización, la gente se va a encontrar separada, esto va ser lo que va a incidir en los primeros hechos de violencia directa.

\section{IV.1 Los primeros hechos de violencia}

Las relaciones sociales se desarrollaron en los llamados campamentos de plásticos, distribuidos en incipientes caletas. Su objetivo era dar cobijo a los pescadores, de manera esporádica o permanente, de acuerdo a las rutas y las temporadas de pesca. El numeroso arribo de aventureros y trabajadores del mar, aumentó el hacinamiento dentro de estos campamentos, y junto con ello, los problemas de convivencia:

(...) cuando llegamos, tuvimos que quedarnos en una parte sólo, porque había mucha gente que no era muy agradable (...) habian personas que tu no sabías de dónde era y de repente se enojaban porque tú lo mirabas $y$ esos no te preguntaban ninguna cosa $y$ derecho a medir la cordura (...) (L. Díaz, com pers. 12 de febrero de 2008).

$\mathrm{Si}$ analizamos los primeros hechos de violencia directa, desde una perspectiva sociológica ambientalista (Bordas, 2011, p. 39), podríamos afirmar que dentro del ecosistema social de las islas, la interacción de diferentes culturas, dieron origen a las primeras manifestaciones violentas: (...) nadie sabía cómo era el otro, habían tantas corrientes (...) entonces esas culturas se atravesaban y cuando no se entendian boom no más choque palizas (...)" (O. Nahuel, com pers. 11 de febrero de 2011).

Las conductas agresivas de algunos sujetos sociales, dentro de las mismas caletas, se transformaron en violencia física y psicológica. Las personas solitarias, eran las más vulnerables dentro de la zona:

(...) cuando había conflicto, eran cuando eran grupos pequeños había un poco de debilidad, pero cuando veían que había un poquito de peso no molestaban (...) algunas personas que andaban solas, eran más vulnerables, a ese tipo de cosas. Por ejemplo, cuando lo encontraba solo, otro que era más aniñao (...) le pegaba o le ponía algunos un corte o algo parecido (...) estaban sectorizados en el fondo (...) depende de cómo tú te presentes en el grupo si ven que eres atontadito o andas sólo, es el más vulnerable (...) (L. Bracho, com pers. 14 de febrero de 2011).

El cambio de residencia de los pescadores y el alejamiento de su círculo social más cercano 
(familia y amigos) incentivó la ingesta de alcohol (Boira, 2010, p. 87) ${ }^{16}$. Estos elementos dieron paso a la violencia anómica (Imbert, 1992, p. $33)^{17}$, y los primeros homicidios:

“(...) en circunstancias que se encontraba en compañia de su hermano (...) y el pescador artesanal (...) en una rancha que lo habitan como casa habitación, llegaron hasta alli (...), en compañía de otros dos individuos desconocidos los que se encontraban en estado de ebriedad y ha raíz de una discusión los agredieron con golpes de palos, puños y pies, asi mismo le ocasionaron heridas con unos cuchillos, ocasionándoles la muerte (...) (Causa Rol No 8.025, Noviembre 1991, Foja $\left.\mathrm{n}^{\circ} 1\right)$.

En Algunos casos, el estado de anomía terminó en suicidio (Durkheim, 2008) ${ }^{18}$ :

\section{(...) paso un poco más de una aproximadamente en que (...) no apareció, por lo que me fui a verlo y al llegar a su rancha lo encontré sin vida pendiendo de una viga de su medigua que estaba construyendo, con una de nylon de unos $3 \mathrm{~mm}$, atada al cuello. Digo a US, que yo lo vi a varios metros de distancia (...) (Causa Rol N 6.910, Enero 1990: Fojas 10- 11).}

La gran cantidad de dinero ganado en las faenas, rápidamente va a ser motivo de robos y peleas. Los migrantes con rasgos delictivos hacian de las suyas:

Hubieron robos de motores (...) se robaban las embarcaciones, de repente en la mañana uno quería ir a su embarcación y ya no estaba (...) todas esas cosas sucedieron por inseguridad, gente que manejaba plata igual

16 El alcohol es una de las sustancias más estudiadas, en su relación con la violencia. Boles y Miotto, 2003, citado por Boira (2010), escribió: "(...) el consumo de alcohol puede justificar un comportamiento inadecuado socialmente, puede interpretar erróneamente las señales entre agresor y la víctima, reduce las inhibiciones impidiendo la conciencia del propio comportamiento e impidiendo la valoración del propio de las consecuencias del mismo (...)" (p. 87). porque a veces se quedaba dos o tres meses (...) tenía que andar la plata en el bolsillo no más, porque el rancho le hacian un corte y entraban, hasta sacar la yerba entraban (...) gala fue la panacea, como era más amplio (...) corría mucha plata (...) (A. Sánchez, com pers. 12 de febrero de 2011).

En ciertas ocasiones, las riñas por robo, terminaron con víctimas fatales:

El día sábado 17 de febrero de este año, alrededor de las seis de la tarde al llegar del lugar de faenas y revisar mi cama debajo de la almohada donde tenía guardada quince mil pesos (...) grande fue mi sorpresa al comprobar que el dinero había desaparecido, entonces, yo de inmediato sospeché en el individuo en el cual habiamos dado hospedaje y que se conocía como el "tajo" (...) yo le dije que tenía que devolverme el dinero y él se molestó (...) yo traté de apaciguarlo (...) él salió de tras mío $y$ me cruzo antes de llegar al bote y saco el cuchillo (...) yo le gané al quien vive (Causa Rol No 6.989, Febrero 1990, Foja 7).

El origen de la violencia directa en puerto Gala y puerto Gaviota, no solamente lo podemos encontrar en las diferencias culturales de las corrientes migratorias o en el estado de anomía en que se encontraban sus habitantes. Existe una raíz más profunda la cual incide en los factores mencionados, nos referimos al aislamiento geográfico y la nula presencia de las instituciones del Estado: (...) en esos años aqui había de todo (...) había gente buena y gente mala (...) se veía la ley del más fuerte (...) (Martínez \& Nahuelquin, com pers. 16 de febrero de 2008).

(...) yo estuve con un bandido una noche, nos acostamos en una casa, un rancho y quería

17 La violencia fundadora, es aquella que está basada en el restablecimiento del orden y es de índole simbólica. La violencia anómica es aquella que se sitúa fuera de la norma.

18 Para Emilie Durkheim, "(...) la anomía da lugar a un estado de exasperación y de cansancio irritado que puede, según las circunstancias, volcarse contra el sujeto mismo o contra otro; en el primer caso produce el suicidio, en el segundo, homicidio (...)" (p. 398) 
matar a (...) [amigo del entrevistado], cerraba los ojos, había una vela y quería que se quede dormido el otro para que lo mate (...) oye gueon le dije yo, ¿me querís matar a mi o al otro hombre? y me paro (...) y me lo agarro del pelo ¿A quién querís matar gueon? ¿Querís matar al hombre que está durmiendo? (...) me dijo Sergio no me mates (...) (S. Alvarado, com pers. 14 de febrero de 2011).

Los testigos directos e indirectos de los hechos de violencia en estas islas no buscaban involucrarse en las peleas o conflictos, ya que sabían que a corto o mediano plazo traería represalias (...) uno ve que están matando a alguien tiene que quedarse callampin no más (...) se escondía la gente para no meterse en problema (...) vive y callabas, el que gritaba estaba jodido (...) (J. Ruiz, com pers. 18 de febrero de 2011).

(...) era preferible guardar silencio callar que tener conflicto acá, era también por temor o por no involucrarse (...) (D. Gallegos, com pers. 17 de febrero de 2011).

La falta de autoridad y de seguridad (Manzano, 2009, p. 78) ${ }^{19}$, hacían necesaria la autoprotección de los pescadores y de algunas familias. Los pescadores que residian hace mucho tiempo en la zona, fortalecieron sus lazos sociales, y esto fue decisivo en el momento de abandonar las islas o vivir para siempre en ellas:

(...) había gente que se dedicaba a hacer otras cosas, que se dedicaba a ayudar a sacar leña a carnear animales, (...) pescábamos a diez minutos (...) nunca se abandonaba el sector y donde veían [los delincuentes] que habian sectores unidos tampoco se metian (...) habian islas donde llegaban cinco o seis personas y

19 Siguiendo el pensamiento de Hobbes: los hombres tienen por derecho natural (jus nature) la libertad para usar el poder con el fin de salvaguardar su vida. La razón los impulsa a defenderse de los otros, sin embargo, la misma razón nos hace ver que mientras se mantenga este derecho, no puede haber seguridad para nadie. Los residentes de nuestros puertos comprendieron que la violencia era un medio legítimo de supervivencia. La inexistencia de la justicia impuesta desde afuera no garantizaba hacian un rancho, esos eran más vulnerables mientras andaban calando (...) (A. Sánchez, com pers. 12 de febrero de 2011).

(...) cuando venían gueones malandrines que venían de otra caleta o venían arrancando para acá uno los cachaba altiro, (...) ¿sabes que es lo que uno hacía? (...) lo aislaba, porque no era parte de su familia que tiene acá (...) (M. Yáñez, com pers. 13 de febrero de 2011).

Los aparatos de coacción del Estado intervenían de manera indirecta dentro de las islas. Su presencia atendía al levantamiento de cadáveres de personas muertas (riñas o accidentes) o personas heridas o enfermas. En algunas ocasiones fiscalizaban el contrabando de alcohol, pero no tenían una presencia directa en los poblamientos espontáneos, por ende, existieron muchos casos criminales que se ocultaron bajo la criminalidad impune (Hikal, 2010, p. 119) ${ }^{20}$

(...) nunca se puso un orden tan grande que diga que es establecieron los pacos unos dos o tres días (...) nunca hubo una tenencia (...) (D. Gallegos, com pers. 17 de febrero de 2011).

(...) cuando habian casos puntuales de que se encontraba alguien herido, peleas o alguien falleció en las playas de repente encontraron gente y venían las patrulleras, a veces venian dos o tres patrulleras en un día (...) (A. Sánchez, com pers. 12 de febrero de 2011).

(...) se preocupaban de controlar el contrabando del vino (...) (Y. Batarse, com pers. 17 de febrero de 2011).

Existieron algunas ocasiones en que

la seguridad de nadie al interior de las islas, por ende, el derecho natural se va a sobreponer al derecho jurídico.

20 La criminalidad impune es el punto medio entre los casos que llegan a conocimiento de las autoridades (criminalidad aparente) y los que terminan en justicia. En el caso de nuestras localidades, la justicia era itinerante, las muertes eran presenciadas exclusivamente, por los residentes en el litoral. 
realizaban visitas para llevar a cabo redadas, con el fin de regularizar la situación judicial de los residentes, empero, no participaban dentro de la vida colectiva de los pescadores.

(...) cuando recién llegué esto era un pueblo sin ley (...) tu papa me conversaba que llegaron carabineros, llegaron los marinos, investigaciones (...) vinieron a hacer como una redada y pillaron gente (...) que se habia arrancado (...) y de ahí nunca más lo hicieron (...) (J. Altamirano, com pers. 17 de febrero de 2008).

Algunas personas que tenían deudas con la justicia o estuvieron involucradas en hechos de sangre, escapaban de las redadas llevadas a cabo (...) hubo detenciones, pero fueron las minimas (...) seguramente ya tenían ubicada la lancha de carabineros (...) arrancaban (...) (M. Ballesteros, com pers. 6 de Marzo de 2008).

La situación judicial de algunos habitantes y su ilegalidad, hacían temer cualquier visita (...) cuando venían los carabineros arrancaban a buscar leña (...) (H. Chaparro, com pers. 17 de Febrero de 2008).

Las autoridades al observar que esta situación se les escapaba de sus manos -su rol era más bien de un espectador- decidieron erradicar de manera definitiva a estos pescadores, a través de la fuerza:

(...) ellos lo que querían era que nosotros salgamos de aquí, no nos querían ver acá, como dos veces vinieron a la casa, [la armada les decía] en ningún momento ustedes pueden hacer una casa aquí, porque esto es fiscal, ustedes no pueden quedarse aquí, asique van a tener que retirarse (...). Pasaban disparando, asustando a la gente (...) aqui cuantas veces pasaron disparando (...) (Coronado-Salas, com pers. 20 de Febrero de 2008).

nos estaban sacando por la fuerza (...) nos aplicaron fuerza a las personas (...) a la propiedad de los pescadores (...) ranchos de madera, les botaban las puertas (...) si nosotros nos sacaban por la fuerza nosotros íbamos a volver al mismo lugar (...) (G. Cristi, com pers. 15 de febrero de 2011).

Al no funcionar la intimidación, se utilizaron los medios legales para terminar con estas ocupaciones:

(...) el Senador Ortiz ha enviado al ministro de Bienes nacionales (...) una carta (...) cuyo texto es el siguiente: Frente a la licitación de islas en la XI Región, creo que es indispensable que respecto de las Islas Toto y Atilio se tenga en especial consideración que se encuentran ambas pobladas, resultando inconvenientes que se vendan, ya que los eventuales adquirientes al parecer, desconocen esta realidad (...) (anónimo, 1990, Enero 26).

La violencia directa exaltó el carácter "primitivo y marginal" de estos pueblos, surgió con el choque cultural de sus habitantes, los cuales se encontraban en un estado constante de anomía (cambio de hábitat). La violencia manifestó siguiendo el patrón sujeto-acciónobjeto (violencia horizontal), y casi no existió ningún obstáculo o freno a estas acciones (temían a las represalias o a terminar involucrados), esto terminó en peleas, robos, homicidios, y en algunas ocasiones en suicidios, ya que no existía ningún control sobre las islas (aislamiento geográfico). La privación de las necesidades básicas de seguridad o supervivencia se vieron vulneradas, ya que el Estado estaba en conocimiento de la situación y no se esforzó por resguardar la integridad física de las personas. La poca atención hacia los pescadores, fue visto como una gran amenaza hacia las autoridades (medios de comunicación y opinión pública), ya que las muertes naturales, violentas y por accidentes, se mantuvieron hasta comienzos de los años noventa ${ }^{21}$. Para dar solución a este problema, el Estado decidió erradicar a los pobladores de las islas, esto cambio el curso de la violencia, ya que tomó un carácter vertical. La asociación entre estos focos vulnerables y sus ocupaciones ilegales (por habitar en terrenos fiscales), pronto pasaron a un plano diferente, dentro de la violencia. Esta tomó un carácter repulsivo y discriminatorio hacia los habitantes de estos pueblos.

21 Para conocer la cantidad de muertes y sus causas, véase a anexo. 


\section{La violencia cultural y/o simbólica} en puerto Gala y puerto Gaviota

Después de tratar los fundamentos de la violencia estructural y directa es necesario cerrar el triángulo de la violencia, utilizando su última tipología (la violencia cultural y/o simbólica). Este tipo de violencia se refiere a todo aquello que desde la cultura legitime y/o promueva la violencia de cualquier origen (Jiménez-Bautista, 2012, p. 111). En nuestro caso particular la violencia cultural es la que terminó por estigmatizar a los pescadores artesanales, y se transformó en el alimento del sensacionalismo mediático:

Desde el incremento de las industrias pesqueras en la Undécima Región, las islas Atilio, Toto y otras, fueron poblándose espontáneamente. Cinco mil personas dedicadas a la pesca artesanal, navegan por los canales, en una amplia zona, donde prácticamente se vivía sin Dios ni Ley (...) (anónimo, 1991, Enero 24).

(...) transformando a Gaviota en la ciudad más violenta, patética del archipiélago. Aquí los pescadores han arrastrado a sus familias, también sus comercios, pero la mayoría son hombres solos, dejados de la mano de dios y del diablo, emborrachados de alcohol, dinero y soledad (...) (Astorga, 1991).

La violencia cultural (García \& Marcuello, 2007, p. 323) fue utilizada como un instrumento de legitimación de la violencia estructural, cuyo fin era desalojar las islas -utilizando la discriminación-, para fines económicos privados:

(...) ese tiempo las autoridades, gobernadora $e$ intendente, llegaron a vender la pomada porque a nosotros nos querían sacar. Aqui habian intereses politicos y salmoneros (...) nos trataron de echar con allanamientos, que habia gente buscada (...) entre autoridades, politica capitalista, engrupámoslos (...) nosotros les ofrecemos; puente, aeródromo (...), en Isla Cuptana (...) hicimos una reunión y dijimos, hemos llegado a un consenso; háganos el puerto, colegio, posta, aeródromo y población, y nosotros nos vamos al tiro, nunca más volvieron pos socio. Cachay que era un interés político para sacarnos de acá, porque (...) se iban a llenar de cultivos acá (...) pensaban que nosotros éramos gente ignorante (...) (V. Coronado, com pers. 12 de febrero de 2008).

Los recuerdos de violencia directa en los poblamientos espontáneos, son los que ejercen un tipo de discriminación cultural, hacia sus habitantes. Esta violencia (Nato \& Rojas, 2008, p. 122) es la que se mantiene a través del tiempo, inclusive hasta nuestros días, siendo pueblos reconocidos por el Estado (...) nosotros no estamos acá porque estamos escondidos, no es porque nos botó la ola (...) no es porque esto sea lo último, lo más rasca (...) nos hemos sentido mal mirados, nos hemos sentido mal tratados $(. . .)^{22}$. (P. Leyton, com pers. 2000).

(...) tú conversas de gala o puerto gaviota conversas afuera por lo menos en Coyhaique, ah esos son de gaviota el pueblo matancero, el pueblo que viola (...) no, si la imagen es mala (...) (O. Hernández, com pers. 15 de febrero de 2011).

A pesar de los fuertes períodos de tensión que se vivieron en estas localidades, por la violencia, posteriormente se inició una nueva etapa dentro del proceso del poblamiento. Esta consiste en la disminución de los procesos migratorios de los pescadores artesanales y el surgimiento de un proceso de sedentarización de sus habitantes, lo cual se enriqueció con la llegada de sus familias y posteriormente la ayuda del Padre José Antonio Ronchi Berra, hasta llegar a transformarse en pueblos reconocidos por el Estado chileno (agosto de 1999).

\section{CONCLUSIÓN}

Si reflexionamos profundamente respecto a la formación de estos pueblos, podríamos decir que toda su historia ha tenido como hilo conductor la violencia, en todas sus manifestaciones. Por 
desgracia, la violencia directa ha sido la más visible y ha dado más credibilidad al mito de los llamados pueblos sin dios ni ley o far west criollo. La utilización de esta tipología de la violencia, en desmedro de sus habitantes, es la que ha ocultado como un iceberg otros tipos de violencia más profundas y destructivas (violencia estructural $y$ simbólica).

Este trabajo ha servido para demostrar que los hechos de sangre en el litoral o la violencia directa, son una transformación de la violencia estructural reinante durante la década de los años ochenta. Este contexto violento se traslado de escenario, desde diferentes regiones, a los desolados parajes de las islas australes, gracias al destape del "boom de la merluza". Por lo tanto, los hechos criminales, son los que van a pasar a formar parte de un estigma, con el cual van a tener que lidiar sus habitantes. Su manipulación va a servir para intentar desalojar las islas que van a habitar desde mediados de los años ochenta, hasta nuestros días (violencia cultural $\mathrm{y} / \mathrm{o}$ simbólica). En concomitancia con nuestro pasado histórico la violencia se puede distinguir como uno de los ejes centrales, dentro de todo el proceso de colonización y poblamiento del litoral, por este motivo, fue de gran ayuda conocer algunos acontecimientos de carácter violento, previos a la formación de nuestros pueblos. Los poblamientos espontáneos pasan a formar parte de todo ese proceso, con una cierta particularidad que los van a destacar. Nos referimos a lo reciente que han sido sus incorporaciones, además de surgir en plena dictadura militar.

La violencia en estas comunidades a fines del siglo XX, nos demuestra el atraso del proceso de poblamiento en la región de Aysén, los hechos acaecidos en nuestras costas parecen formar parte de una anacronía histórica, la cual se asemeja a un relato de los inicios de la colonización interior. Sin embargo, si analizamos nuevamente el contexto en el cual se van a originar, nos vamos a encontrar con la dictadura militar, por lo tanto, no es de extrañarse que todo el proceso haya tenido como protagonista la violencia.

Uno de los hechos curiosos es que este proceso de migración fue paralelo a la colonización de Melimoyu -y sectores aledaños- la cual tenía como misión acabar con la mala racha de los intentos fallidos de colonizaciones anteriores (La isla de los Leones y Quitralco), sin embargo, se va a transformar en un fracaso más dentro de los llamados asentamientos dirigidos por el Estado. Puerto Gala y puerto Gaviota, a pesar de ser poblamientos espontáneos, cumplieron el sueño que no pudo materializar el Estado. Estas reflexiones son las que nos hacen plantearnos algunas interrogantes, para futuros trabajos: ¿Por qué motivos los pescadores decidieron establecerse en estas islas, a pesar de todos los problemas que han tenido? ¿Por qué un poblamiento espontáneo pudo más que una colonización dirigida por el Estado?

Finalmente podríamos decir que este trabajo ha servido para demostrar, a través de un pequeño ejemplo, la realidad de la pesca artesanal, la cual se encuentra sumida en una profunda crisis. Su población actual ha ido disminuyendo considerablemente debido a sus bajas cuotas de extracción y la falta de apoyo externo. La industria salmonera, la cual detenta los sectores que tradicionalmente han ocupado los pescadores (Saavedra, 2013) y la pesca industrial, están provocando una serie de cambios en la forma de vida de estos trabajadores de mar. La mayoría de la población ha tenido que emigrar a los centros poblados más cercanos (puerto Cisnes, puerto Raúl Marín Balmaceda, Aysén, etc.), debido a la falta de trabajo. Las llamadas "pesqueras" se han encargado de "readaptar e insertar laboralmente" a estos pescadores, a través del sistema de trabajo formal, en el cual han ido perdiendo la libertad de ofrecer su pesca al mejor postor, y junto con ello las oportunidades de surgir en base a sus propias iniciativas.

\section{AGRADECIMIENTOS}

Quiero dar las gracias a todos los pescadores artesanales de puerto Gala y puerto Gaviota, en especial a todas las personas que participaron en las entrevistas (Sergio Alvarado, Paulo Leyton, Mylene Muñoz, Víctor Ramírez). A Mauricio Osorio Pefaur y Enrique Martínez Saavedra, por apoyarme en la revisión y redacción de este trabajo. A la profesora de Inglés Andrea Durán, por su valiosa traducción del resumen. Al ingeniero forestal Carlos Castillo Levicoy, por ayudarme a confeccionar el mapa de los poblamientos 
A. MARÍN

espontáneos y los gráficos. Al abogado Carlos Carvacho, por apoyarme en la citación de fuentes judiciales, al Chelo, por conseguir información en la Armada de Chile, al Juzgado del Crimen de Puerto de Aysén (Mario Ballesteros y Mauricio Tillería). A don Ricardo Ortiz Barría por su gran ayuda brindada en la búsqueda de los anuarios estadísticos de Carabineros de Chile. A toda mi familia por su ayuda incondicional, en especial a Claudia Marín Lleucún, por la revisión de las actas de defunción en Puerto Aysén.

En memoria de María Teresa Lleucún Burgos (Gracias mamá), Bruno Carmona, Oscar Nahuel, Oscar Soto Bello, El Calí, Armando Pillancari, el Chelino y el Padre José Antonio Ronchi Berra (Gracias Padre).

\section{BIBLIOGRAFIA}

Aguero, M. (1992). Contribuciones Para El Estudio de la Pesca Artesanal en America Latina: Proceedings of the Mini-Symposium on Small-Scale Fisheries of the 46th International Congress of Americanists, 4-8 July 1988, Amsterdam, the Netherlands. Manila: ICLARM.

Armada de Chile - DIRECTEMAR (2012). Análisis Estadístico Accidentes Laborales 2012. Chile: Armada de ChileDIRECTEMAR.

Boira, S. (2010). Hombres maltratadores. Historias de violencia masculina. España: Universidad de Zaragoza.

Bordas, J., Baeza, J. C., \& Alba, C. (2011). Temas de sociología criminal. Sociedad, delito, víctima y control social. Madrid: UNED.

Durkheim, E. (2008). El suicidio (6º edición). Madrid: Ediciones AKAL, S.A.

Fisas, V. (1998). Cultura de paz y Gestión de conflictos. Barcelona: Icaria Editorial.

Galtung, J. (1995). Investigaciones teóricas: Sociedad y Cultura contemporáneas. Madrid: Tecnos-Instituto de Cultura "Juan Gil-Albert».

Galtung, J. (2003). Paz por medios pacíficos. Paz y conflicto, desarrollo y civilización. Barcelona: Bakeaz/Gernika Gogoratuz.

García, A., \& Marcuello, C. (2007). Conceptos Para Pensar El Siglo XXI. Madrid: Los Libros de la Catarata.

Hikal, W. (2010). Introducción a la criminología. Nicaragua: Jurídica.

Imbert, G. (1992). Los Escenarios de la Violencia: Conductas Anómicas y Orden Social en la España Actual.
Barcelona: Icaria Editorial.

Jiménez-Bautista, F. (2012). Racionalidad pacífica. Una introducción a los estudios para la paz: Una introducción a los estudios para la paz. Madrid: Editorial Dykinson.

La Parra, M., \& Tortosa, J. (2003). Violencia estructural: una ilustración del concepto. Documentación Social 131 (¿?), 57-72.

Manzano, L. (2009). Violencia en los barrios críticos. Explicaciones teóricas y estrategias de intervención basadas en el papel de la comunidad. Santiago de Chile: RIL Editores.

Martínez, M. A. (1997). Pobreza y exclusión social como formas de violencia estructural: la lucha contra la pobreza y la exclusión social es la lucha por la paz. Alternativas. Cuadernos de Trabajo Social 5(oct.), 17-36.

Moulian, T. (2002). Chile actual: anatomía de un mito. Santiago de Chile: LOM Ediciones.

Nató, A., \& Rojas, C. (2008). Geografía del conflicto: claves para decodificar la confrontación social y política. La Paz: Plural Editores.

OECD (2009). Políticas de pesca y acuicultura de Chile Informe de base. Chile: OECD Publishing.

Rozenblum, S. (2007). Mediación: Convivencia y resolución de conflictos en la comunidad. España: GRAÓ.

Vásquez, F. (2002). PIERRE BOURDIEU: la sociología como crítica de la razón. España: Editorial Montesinos.

Weinstein, J. (1989). Los Jóvenes pobladores en los años en las protestas nacionales (1983-1984), una visión sociopolítica. Santiago de Chile: CIDE.

Yépez, I., \& Herrera, G. (2007). Nuevas migraciones latinoamericanas a Europa: balances y desafíos. Ecuador: Flacso.

\section{FUENTES IMPRESAS}

Anónimo. (1986, Septiembre 26). Pescador Perdió Implementación. El Diario de Aysén, p. 4.

Anónimo. (1987, Septiembre $1^{\circ}$ ). Pescadores artesanales se quejan por incursiones Buques de Factoría. El Diario de Aysén, p. 4.

Anónimo. (1991, Enero 24). Reten Flotante en el Litoral Norte. El Diario de Aysén, p. 6.

Anónimo. (1990, Enero 26). Hugo Ortiz considera Inconveniente Licitación Islas Toto y Atilio, El Diario de Aysén, p. 11.

Anónimo. (1991, Junio 03). Pescadores de Puerto Gaviota viven muy Mal. El Diario de Aysén, p. 5.

Anónimo. (1993, Julio 05). Pescadores y Colonos de Melimoyu 
Piden Títulos, El Diario de Aysén, p. 6.

Arellano, V. (1986, Agosto 29). Entre el fracaso y la supervivencia: la realidad de los nuevos colonos evangélicos de Santo Domingo. La Segunda, pp. 1821.

Leal, L. (1986, Octubre 30). Buques de factoría no deben seguir en Aysén. El Diario de Aysén, p. 7.

Brinck, G., Díaz, R., Morales, C., \& Marín, A. (2011). Las Mutaciones de La Merluza Austral Historia, cultura y economía política en Isla Toto/Puerto Gala. Santiago de Chile: Editorial Cuarto Propio.

INE. (2007). Migración Interna Regional 1992-2002. Santiago de Chile: INE

Mena, F. (1985). Presencia indígena en el litoral de Aisén. Revista Trapananda Año VIII, N5, Coyhaique, 212

Morales, A. (2012). "La política criminal contemporánea: Influencia en Chile del discurso de la ley y el orden". Polit. crim. Vol. 7, No 13 Art. 3, pp. 94 - 146

Osorio, M. (2012). Un episodio de violencia en el Baker: la muerte de tres Kawésqar en Bajo Pisagua (4746'S $\left./ 73^{\circ} 35^{\prime}\right)$,1931. Revista Magallania, 40 (2) 41-60.

Oviedo, E. (2008). Temor, delitos y violencias en Santiago, Artículo inédito, 1-11. Recuperado en: http:// comunidadyprevencion.org/wp/?p=298

Saavedra, G. (2005). Las economías silenciosas del litoral Aisenino. En M. Osorio (Ed.), Otras narrativas en Patagonia. Tres miradas antropológicas a la Región de Aisén. Santiago de Chile: Ediciones Nire Negro (colección de ensayos). 35-63.

Saavedra, G. (2013). La pesca artesanal en las encrucijadas de la modernización. Usos, apropiaciones y conflictos en el borde costero del sur de Chile. Revista Andaluza de Antropología 4 (marzo), 79-102.

Salinero, S. (2012) ¿Por qué aumenta la población penal en Chile?: Un estudio criminológico longitudinal. Revista Ius et Praxis, Año 18, No 1, 113 - 150

Subsecretaría de Pesca (1981). Diagnóstico del subsector pesquero artesanal. Revista Chile Pesquero, 16, 9

Universidad de Chile (Centro de Análisis de Políticas Públicas Área de Desarrollo Sustentable). (1999). Estado del Medio Ambiente en Chile - 1999. Colección Sociedad Estado y Políticas Públicas. Gobierno de Chile, Comisión Nacional del Medio Ambiente. Santiago de Chile: LOM ediciones
Weber, A. (1903). Chiloé su estado actual- su colonización. Su porvenir. Santiago de Chile: Imprenta Mejía.

Westhoff, F. (1867). Memoria del subdelegado marítimo del archipiélago de los Chonos o Guaitecas. Anales de la Universidad de Chile XXIX, 445-474.

\section{RECURSOS AUDIOVISUALES}

Astorga, P. (1991). Las ciudades de plástico [video Cassete]. Programa El Mirador. Chile: Santiago.

London, P. (2000). Isla Toto [video Cassete] Programa Tierra Adentro, con todo lo nuestro. Chile: Santiago.

\section{FUENTES INÉDITAS}

Causa Rol n 6.624-Agosto de 1989, Juzgado del Crimen de Puerto Aysén, fojas 1-10.

Causa Rol $n^{\circ}$ 6.663-Agosto de 1989, Juzgado del Crimen de Puerto Aysén, fojas 1-12.

Causa Rol n 6.861.-Diciembre de 1989, Juzgado del Crimen de Puerto Aysén, fojas 1-7.

Causa Rol n 6.862-Diciembre de 1989, Juzgado del Crimen de Puerto Aysén, fojas 1-8.

Causa Rol n 7.459-Febrero de 1991, Juzgado del Crimen de Puerto Aysén, fojas 2.

Causa Rol n 8.025-Noviembre de 1991, Juzgado del Crimen de Puerto Aysén, foja 1.

Causa Rol n 6.910-Enero de 1990, Juzgado del Crimen de Puerto Aysén, fojas 10-11.

Causa Rol No 6.989-Febrero 1990, Juzgado del Crimen de Puerto Aysén, foja 7.

Aránguiz, E. (1988). Viabilidad y Adaptación de los Sistemas sociales un estudio antropológico histórico sobre el experimento colonizador de Quitralco. (Tesis inédita para optar al grado de licenciado en Antropología). Universidad de Chile. Santiago de Chile.

Ramírez, V (1998). Grupo Gala: Estudio de un poblamiento espontáneo en el litoral norte de la undécima región. (Tesis inédita para optar al grado de licenciado en educación, profesor de Historia y Geografía), Concepción.

Registro Civil de Puerto Cisnes (1985-1993), Actas de Defunción, localidades de puerto Gala y puerto Gaviota (1985-1993), Puerto Cisnes. Chile. 


\section{ANEXOS}

Datos estadísticos criminales, XI Región de Aysén y Provincia de Aysén.

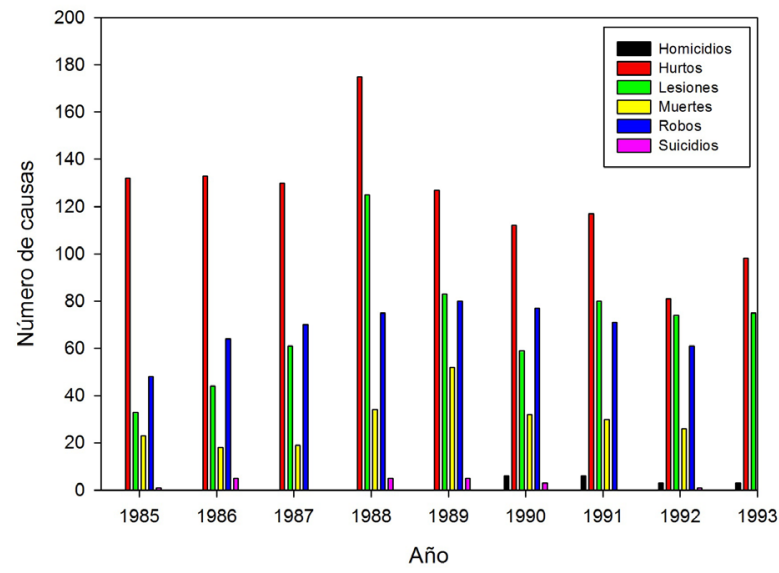

Fig. 1. Causas criminales en la provincia de Aysén. Período 1985-1993.

Los registros estadísticos de aprehendidos y causas criminales (1985-1993) muestran las cifras de delitos cometidos, en contra de las personas

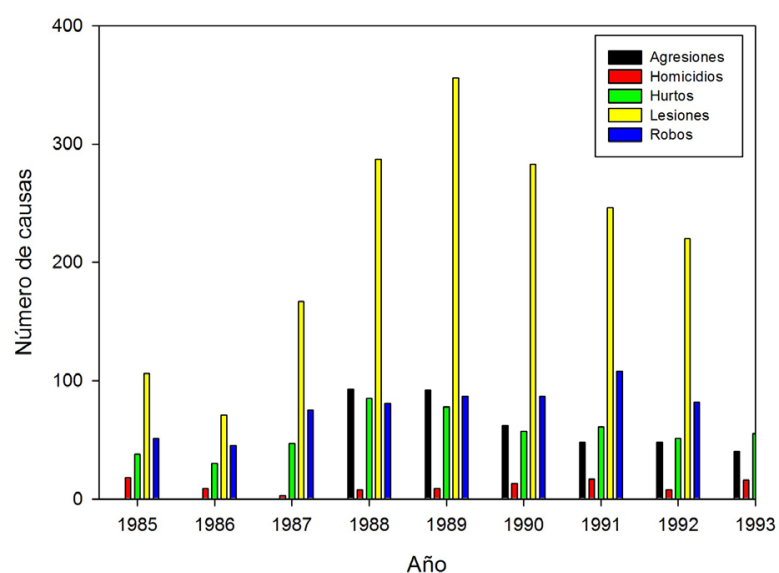

Fig. 2. Total aprehendidos, región de Aysén. Período 1985-1993.

(muertes, homicidios, suicidios, agresiones, pendencias, riñas, lesiones graves y menos graves) y la propiedad (robos y hurtos).

Total Región de Aysén, delitos cometidos en contra de las personas y la propiedad (1985-1993):

Tabla. 1. Total de delitos contra las personas.

\begin{tabular}{|l|c|}
\hline Lesiones graves, menos graves y leves & 1922 \\
\hline Agresiones, pendencias y riñas sin lesiones & 383 \\
\hline Homicidios & 101 \\
\hline
\end{tabular}

Tabla 2. Total delitos contra las propiedades

\begin{tabular}{|l|l|}
\hline Robos & 687 \\
\hline Hurtos & 502 \\
\hline
\end{tabular}

Tabla. 3. Años con mayor cantidad de delitos.

\begin{tabular}{|l|l|}
\hline 1988 & 554 \\
\hline 1989 & 622 \\
\hline 1990 & 502 \\
\hline 1991 & 480 \\
\hline
\end{tabular}

Tabla 4. Delitos contra las personas y la propiedad.

\begin{tabular}{|l|c|c|c|c|c|}
\cline { 2 - 7 } \multicolumn{1}{c|}{} & 1988 & 1989 & 1990 & 1991 & Total \\
\hline Lesiones graves, menos graves y leves & 287 & 356 & 283 & 246 & 1172 \\
\hline Agresiones, pendencias y riñas sin lesiones & 93 & 92 & 62 & 48 & 295 \\
\hline Homicidios & 8 & 9 & 13 & 17 & 47 \\
\hline Robos & 81 & 87 & 87 & 108 & 363 \\
\hline Hurtos & 85 & 78 & 57 & 61 & 281 \\
\hline
\end{tabular}


Total Provincia de Aysén, delitos cometidos en contra de las personas y la propiedad (1985-1993):

Tabla. 5. Total de delitos contra las personas.

\begin{tabular}{|l|c|}
\hline Lesiones & 634 \\
\hline Muertes & 258 \\
\hline Homicidios & 18 \\
\hline Suicidios & 21 \\
\hline
\end{tabular}

Tabla. 7. Años con mayor cantidad de delitos.

\begin{tabular}{|l|l|}
\hline 1988 & 414 \\
\hline 1989 & 347 \\
\hline 1990 & 280 \\
\hline 1991 & 304 \\
\hline
\end{tabular}

Tabla 6. Total delitos contra las propiedades.

\begin{tabular}{|l|c|}
\hline Robos & 620 \\
\hline Hurtos & 1105 \\
\hline
\end{tabular}

Tabla 8. Delitos contra las personas y la propiedad.

\begin{tabular}{|l|c|c|c|c|c|}
\cline { 2 - 7 } \multicolumn{1}{c|}{} & 1988 & 1989 & 1990 & 1991 & Total \\
\hline Lesiones & 125 & 83 & 59 & 80 & 347 \\
\hline Muertes & 34 & 52 & 32 & 30 & 148 \\
\hline Suicidios & 5 & 5 & 3 & - & 13 \\
\hline Homicidios & 1 & - & 6 & 6 & 13 \\
\hline Robos & 75 & 80 & 77 & 71 & 303 \\
\hline Hurtos & 175 & 127 & 112 & 117 & 531 \\
\hline
\end{tabular}

Al comparar las cifras delictuales a nivel regional y provincial, claramente se puede observar que no existe mucha diferencia en los años que se presentan la mayor cantidad de los delitos, además, poseen una cierta similitud en su naturaleza. El período que comprende desde el año 1988 hasta el año 1991, guarda relación con el período de transición a la democracia, en nuestro país. En estos años, hubo un aumento en los delitos que mencionamos. El origen de esta violencia delictual, se encuentra ligada a la apertura de la economía chilena, y a su vez, a la pérdida del Estado social, en materia laboral y de seguridad social (Oviedo, 2008, p. 6). Esto puede explicar el aumento de los delitos, en contra de la propiedad y las personas, ya que los robos y los hurtos, en muchos casos, están relacionados con las lesiones, agresiones y homicidios.

Desde el punto de vista delictual, en 1980 la población carcelaria chilena ascendía a 15.270 personas, en 1985 , experimentó un alza de $33 \%$ y su universo era de 20.242 personas. Para comienzos de la década de los noventa, la población recluida alcanzaba las 22.593 personas (Salinero Echeverría, 2012, p. 116). A finales de la década de los ochenta se observó una pacificación de los aparatos de coacción, se bajó la encarcelación, así también, se produjo una disminución de la sanciones, se desarrolló un sistema basado en multas y en servicios comunitarios. La concesión de beneficios intrapenitenciarios, entre los años 1989 y 1992 , disminuyeron la población carcelaria (Morales, 2012, p. 102). Es bastante probable que exista una relación entre estas reformas, y el proceso de migración que experimento una parte de las corrientes migratorias. Esto se puede explicar, tomando en cuenta el dinamismo económico que se vivió a mediados y finales de la década de los ochenta, junto con las oportunidades laborales (Saavedra, 2005: 57-61) que ofrecía el mar (pesca demersal, pesqueras, explotación de recursos bentónicos, etc.). Prueba de ello, son las tasas de inmigración, emigración y migración neta en la Región de Aysén, entre los años 1987 y 1992 (INE, 2007, p. 14 y 18), la tasa de inmigración alcanzó los 23,0 y la tasa de emigración alcanzó los 23,2, por lo tanto la tasa de migración neta, fue de $-0,2$, esto nos demuestra que hubo una gran cantidad de población golondrina, posiblemente su arribo, concuerda con la búsqueda de trabajo y oportunidades. 
Fig. 3. Personas fallecidas en Puerto Gaviota.

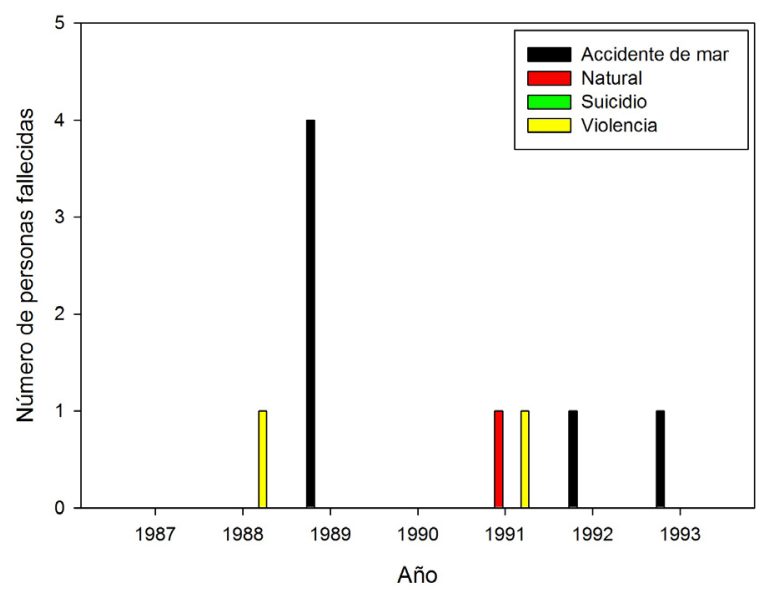

Tabla 9. Región. Total homicidios.

\begin{tabular}{|c|c|c|}
\cline { 2 - 3 } \multicolumn{1}{c|}{} & Puero Gala & Puerto Gaviota \\
\hline $1985-1993$ & $0,9 \%$ & $1,9 \%$ \\
\hline $1988-1991$ & $2,1 \%$ & $4,2 \%$ \\
\hline 1991 & $0 \%$ & $16,6 \%$ \\
\hline 1990 & $7,6 \%$ & $0 \%$ \\
\hline 1988 & $0 \%$ & $12,5 \%$ \\
\hline
\end{tabular}

Al observar la información que nos entregan los gráficos, el total de muertes pesquisadas, suman un total de 19 personas, de sexo masculino (puerto Gala 10 y puerto Gaviota 9). La causa de muerte que presenta mayor cantidad de fallecidos corresponde a los accidentes de mar (12), de los cuales, 6 pertenecen a puerto Gala y 6 casos involucraron a puerto Gaviota. A continuación les siguen las muertes violentas, ya sea por homicidio, trifulcas o robos con resultados fatales (1 puerto Gala y 2 puerto Gaviota), posteriormente encontramos las muertes naturales ( 2 puerto Gala y 1 puerto Gaviota) y finalmente se halló un deceso por suicidio en puerto Gala. Si comparamos las cifras criminales regionales y provinciales, con nuestros objetos de estudio, podríamos decir que no existe un referente de comparación, respecto a los accidentes de mar. Sin embargo, podemos cotejar las cifras de muertes violentas, naturales y un caso de suicidio.
Fig. 4. Personas fallecidas en Puerto Gaia.

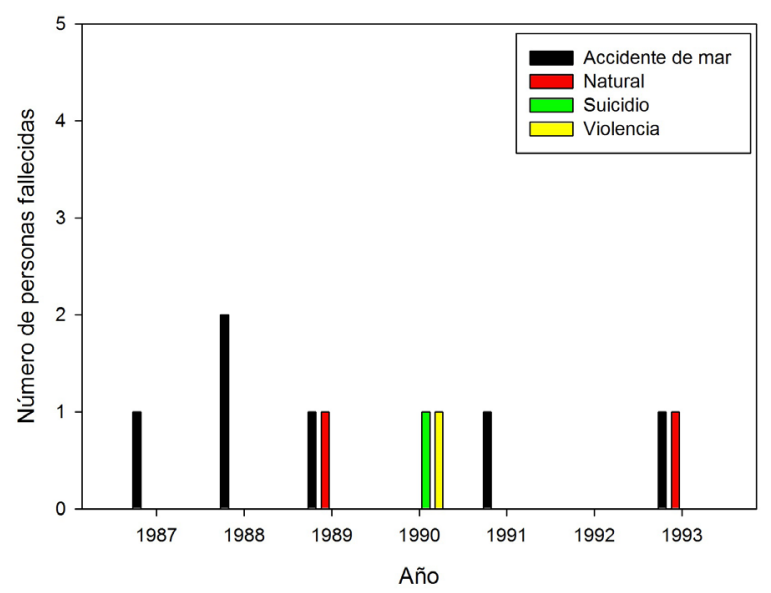

Tabla 10. Provincia. Total homicidios.

\begin{tabular}{|c|c|c|}
\cline { 2 - 3 } \multicolumn{1}{c|}{} & Puero Gala & Puerto Gaviota \\
\hline $1985-1993$ & $5,5 \%$ & $11,11 \%$ \\
\hline $1988-1991$ & $7,6 \%$ & $15,3 \%$ \\
\hline 1991 & $0 \%$ & $16,6 \%$ \\
\hline 1990 & $16,6 \%$ & $0 \%$ \\
\hline 1988 & $0 \%$ & $100 \%$ \\
\hline
\end{tabular}

Muertes violentas, naturales y suicidio

Las muertes violentas corresponden a homicidios (doloso, preterintencional y simple). Sus causas, se relacionan con: un robo (1990) y una riña fatal (1991) en puerto Gala y una violación de morada (1988) en puerto Gaviota. La chispa detonante de los dos primeros fue el alcohol. En el último, el occiso pensó que era objeto de un asalto.

Las cifras nos muestran que a nivel regional, no existe mucha incidencia en la cantidad de muertes provocadas desde 1985-1993, sin embargo, en el período de 1988-1991 sufre un leve aumento (población flotante), concuerda con los años 1988 y 1991 (Pto. Gaviota) y 1990 (Pto. Gala). A nivel provincial la situación cambia, ya que el impacto de los homicidios aumenta, en el año 1988, Pto. Gaviota representa el único homicidio en la Provincia de Aysén. Entre los años 1990 y 1991, 
ambas islas, simbolizan un $16,6 \%$ de los homicidios provinciales $^{23}$. En los casos de muerte por violencia directa, los constantes movimientos de población, en un espacio reducido y la gran cantidad de dinero que se ganaba en poco tiempo, generó peleas, robos, homicidios, etc. El elemento principal que dio pie a este tipo de violencia fue la ingesta de alcohol, la migración de personas con rasgos delictivos ${ }^{24}$ (deudas pendientes con la justicia), y el aislamiento geográfico. Las causas de muerte naturales, fueron provocadas por decesos fulminantes (accidente vascular, paro Cardiorrespiratorio y senilidad), los cuales, no tuvieron atención médica y se vieron afectados por las distancias de los centros hospitalarios. En el caso de suicidio (asfixia por ahorcamiento) la causa del deceso fue por motivos familiares.

\section{Accidentes de mar}

Los casos de muerte por accidentes de mar, suman un total de 12 (6 en ambas islas), las causas hacen mención a asfixia por inmersión, hipotermia por inmersión, asfixia por cuerpo extraño, asfixia por sumersión y un accidente provocado por arma de fuego. Estas tipologías de muertes (ARMADA DE CHILE - DIRECTEMAR, 2012, p. 10) fueron las más numerosas y pueden considerarse como un elemento de continuidad en los procesos migratorios de nuestras islas ${ }^{25}$ (a excepción del accidente por arma de fuego), debido a la gran cantidad de población flotante que se encontraba en las faenas marítimas (Agüero, 1992, p. 14) ${ }^{26}$. La pesca artesanal es una de las actividades económicas más peligrosas en el mundo laboral, debido a los naufragios que pueden sufrir los pescadores (peligro constante). En nuestros casos, las probabilidades de sufrir un accidente se incrementaron, debido a las precarias condiciones de sus embarcaciones (inicialmente se desplazaban a remo, además de ser remolcados por embarcaciones medianas y mayores), la

23 Es importante mencionar, que la baja densidad de población de la Región de Aysén, inciden en la cantidad de muertes, tanto a nivel provincial y comunal.

24 En uno de los homicidios, la persona fallecida, presentaba antecedentes penales: 2 causas, una por robo y hurto (1975 y 1977), 2 órdenes de aprensión por robo y hurto (1982 y 1988), además de dos arraigo por Pleno Derecho, por haber sido declarado reo que indica: lesiones (1986) y hurto (1989). Véase Of. $\mathrm{s} / \mathrm{n}$ de 04.01.91, Causa $\mathrm{N}^{\circ}$ inexperiencia en la pesca (aventureros), la presencia del alcohol (venta ilegal), la falta de fiscalización por parte de las instituciones del Estado (muchos, no eran trabajadores del mar y no tenían carnet de pescador artesanal) y las inclemencias del tiempo (temporales), fueron los factores que incidieron en muchos naufragios y muertes por inmersión y sumersión.

\section{Las fuentes y sus incógnitas}

Las fuentes consultadas corresponden principalmente a los archivos del Juzgado del Crimen de puerto Aysén, en el cual, se lograron rescatar 8 casos de muertes y las actas de defunción del Registro Civil de puerto Cisnes, en las cuales, se pesquisaron 11 fallecidos (incluye 3 casos que concuerdan con los archivos judiciales). Se revisaron los archivos del Registro Civil de puerto Aysén y puerto Raúl Marín Balmaceda, las capitanías de puerto Cisnes y puerto Aysén, Carabineros de Chile (puerto Aysén y puerto Cisnes), la PDI, hospitales (puerto Cisnes y puerto Aysén), el SML y no se encontró información de personas fallecidas en estas islas.

Al contemplar los casos y leer sus testimonios, se puede apreciar el contexto del llamado boom de la merluza. Estas fuentes nos permiten tener una visión general de cómo se desenvolvieron los pescadores y aventureros (vida cotidiana, faenas, ocupaciones, etc.). También nos entrega una descripción de las personas que frecuentaban las islas y del terreno en que vivían (estimación de la población flotante, lugar de procedencia, accesos, aislamiento geográfico, etc.). Si analizamos las causas judiciales de manera individual, es posible encontrar una serie de elementos, los cuales dejan una gran cantidad de dudas respecto a la cifra oficial de muertes y sus causas. Existen casos en los que no se lograron esclarecer las muertes violentas o por accidentes (inmersión, sumersión, manipulación

6.989.

25 En nuestros casos, los orígenes de las muertes corresponden a distintos tipos de accidentes, según la Armada de Chile, reciben el nombre de caída al mar y muerte por inmersión.

26 En 1989 nuestro país poseía aproximadamente 15.000 embarcaciones (motor fuera de borda $35.5 \%$, bote a remo o vela $29 \%$ y lancha $16 \%$ ). 
de arma de fuego, robo, etc.), ya que los testigos presenciales y las pruebas eran pocas y en algunas ocasiones no existieron, por lo tanto, no se sabe con exactitud lo que sucedió. A esto debemos agregar la itinerancia de Carabineros y la Armada, no tenían una presencia directa y constante en las islas del litoral (falta de recursos, pésimas condiciones climáticas, etc.), por lo tanto, su labor se vio obstaculizada. Existe una gran posibilidad de que la cifra de fallecimientos haya sido mayor, de las que se tiene registro, no solamente por los hechos de sangre resaltados por los medios de comunicación, sino que también por accidentes o muertes naturales. Dentro de la memoria colectiva de los habitantes de estas islas, quedaron muchas defunciones y delitos que nunca llegaron a manos de la justicia. Hoy en día, perduran los recuerdos de los protagonistas y los testigos de estos hechos, los cuales, se pueden contrastar con algunos relatos trágicos mencionados en los archivos revisados, no obstante, existen otros que no aparecen en dichas fuentes.

Fig. 5. Mapa de los poblamientos espontáneos.

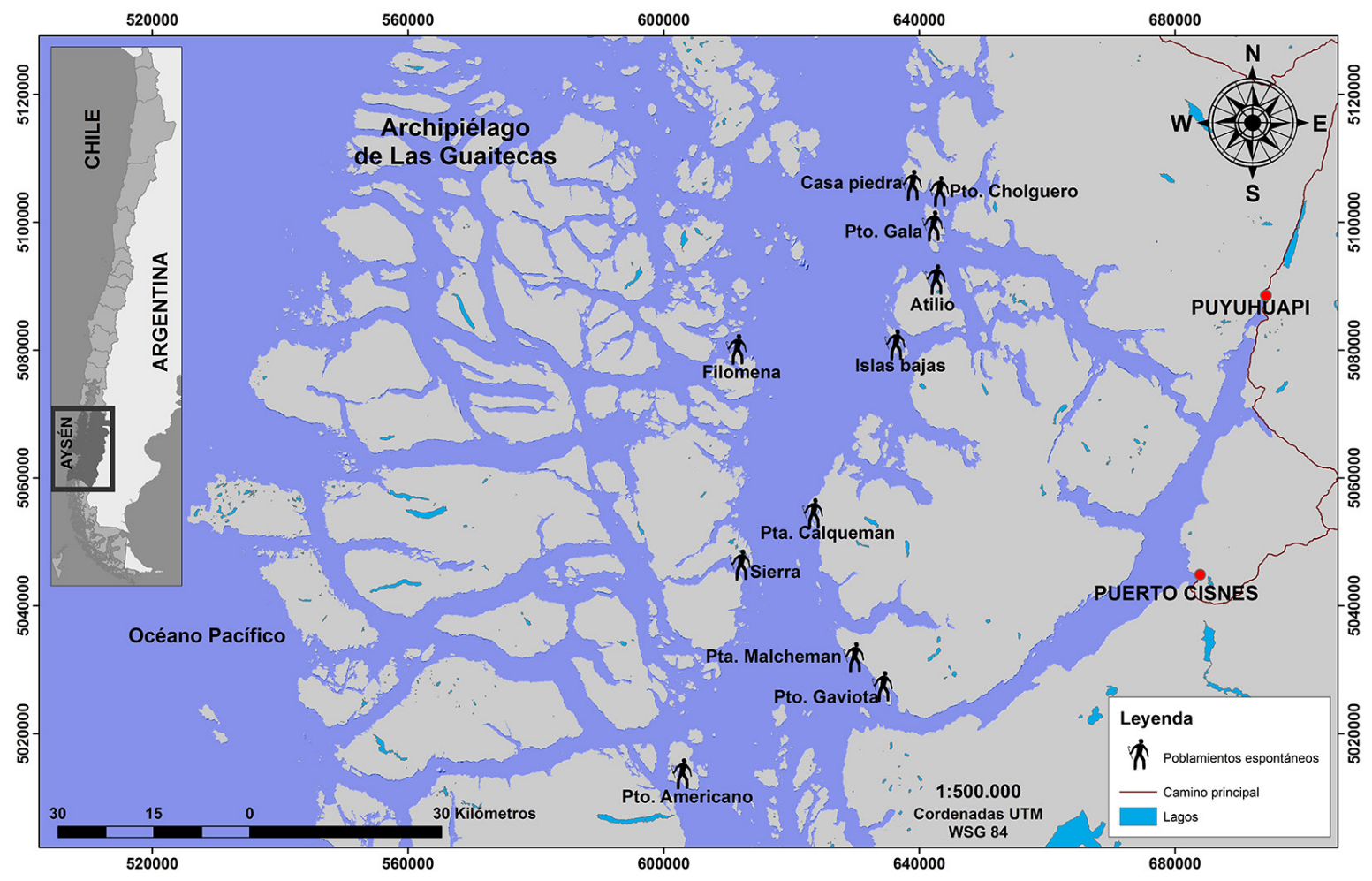

